\title{
Assessing Financial Transaction Bank Credit Cards According to Islamic Banking System
}

\author{
Ahmed El-Murdi Saeed Omar \\ Professor, Department of Islamic Studies, \\ Faculty of Shariah and Islamic Sciences \\ University of Alwasl \\ Dubai, United Arab Emirates \\ E-mail: ahmedelmurdi@yahoo.com/ ahmedelmurdi@gmail.com
}

Phone: 00971504751430

\begin{abstract}
This research explored the historical background to bank credit cards, the development of using plastic cards, classification of bank cards, characteristics and benefits of each class of cards. The research intends to address presumed problems such as: what are bank credit cards? How it has been developed? What are the international organization that introduced plastic cards? How these companies settle the payment between the card holder, the bank where he opened account and the business center, where he purchased goods or enjoyed services? Descriptive analytical methodology was employed for analysis whereby the research described type of bank cards, classified them and then collaborate analysis with the usage and benefits of each card. The thrust of the paper is to explore the views of Shariah Law pertaining the legality of using plastic bank credit cards, describing the acts and behavior which is not lawful according to provisions of Shariah Law. Moreover it includes the legal basis for collecting fees by bank managements on services being offered to credit card holders.
\end{abstract}

Key words: Bank credit cards. Visa, Master card, Amex, American express, Juristic resolution, Fatwas International Islamic juristic assembly.

Journal Reference Format:

Ahmed El-Murdi Saeed Omar (2020) Assessing Financial Transaction Bank Credit Cards According to Islamic Banking System. Behavioural Informatics, Digital Humanities \&Development Journal Vol 6. No. 1.Pp 99-106. SMART Research Group, International Centre for IT \& Development (ICITD), Southern University Baton Rouge, LA, USA. C Creative Research Publishers. Article DOI No - dx.doi.org/10.22624/AIMS/BHI/V6N2P4

\section{INTRODUCTION \& LITERATURE WORK}

There exist historical antecedents to bank credit cards usage, their characteristics and benefits of each class of cards. Various authors wrote papers, books and post graduate thesis on this topic, presented and published in different languages such as Al baaly, Abdalhameed Mahmoud (2004): Bitagat Aiitiman El masrifiyah, maktabat wahabat; Ali el saloos (1423H): Mausoat El gadaya El-fiqyat Al muasirat, $7^{\text {th }}$ edit, Dar althagafat, Qatar; Al- habahi, Anas (2005) : El-nizam Alganouni , Libitagat Al iltiman, first publish : Dar al halabi, and El -tiwaijari, Yousif Bin Abdulaziz (1431H): Al nugood El-ilaktroniyah, Ph.d thesis in Islamic Law, Riyadh, Saudi Arabia. The discourse in this paper will be delineated into four parts viz:

1. Definition and historical background of bank credit cards:

2. Characteristics and benefits of credit cards.

3. Types of the credit cards.

4. Islamic Jurisprudential Provisions on usage of Bank Credit Cards: 


\section{DEFINITION AND HISTORICAL BACKGROUND OF BANK CREDIT CARDS :}

The specialist in the filed finance' banking and economist provide various definitions for bank credit cards such as:-(1)

1. Credit card could be defined as a payment card that enables the holder to make purchases and to draw cash up to pre-arranged limited.

2. A bank issued card that allows consumers to purchase goods or services from a merchant on credit.

3. A piece of plastic used instead of cash or cheques authorizing payment for goods and services, etc... In addition to other synonymous definitions which bears correspondent meaning.

\section{Historical Background}

With reference to British encyclopedia the Briticiana the usage of credit cards commenced earlier since 1920's at limited states of America .at the initial stage the individual companies such as hotels and oil field stations starting issuing them for customers to clear their purchases. This phenomena increased widely in the years .post 11 world war.

The foremost cards that used official for the first time the one that issued and introduced by Diner club by 1950 . According to this financial system the companies offering the customers the cards for annual fee and bill them on monthly basis on the other hand another universal card was established in1958, it was American Express Company.

Then later credit card system was explored, at this stage the companies and banks credit the account of merchant the sales of goods and offering then card holders at the end of the period, then the customer in return will either pay the bank the whole balance or in monthly installments with interest.

The first national bank that started plan nationwide basis was bank of America in 1959 at California. The policy and financial system of this bank was licensed in other states in 1966 and later was visa card in 1976.

Then later in the following years MasterCard was appeared and registered.(2)

\section{CHARACTERISTICS AND BENEFITS OF CREDIT CARDS:-}

As the specialist mentioned earlier on the definition of credit card that" is a plastic card with measured size and edge, where the name secret number and other unseen details are included, it qualifies enabling the customer to withdraw cash money and pay the cost of purchases either the holder of the card is an individual or organization. (3) Therefore the characteristics could be summarized as follows:-

Firstly:-

The credit card required association of three participants as follows ; the bank that issued the credit card, the customer the card holder and the merchant. Now let me highlight these three relationships; (4)

1. The banks that issued VISA and MasterCard allowed the customer to clear the charges of their purchased goods everywhere globally.

2. The second function of the credit card it assumed as a source of international currency, if you have the card you may insert at in ATM machine at US, France, Russia anywhere in the world you will be eligible to get that currency through the cash dispenser which are linked to either visa or Master Card Company.

3. Credit card played another role it qualify the holder to borrow any amount of the money from the bank to certain level which restricted by the bank that issued the card until certain level. 


\section{Secondly:-}

Flexibility and convenience of payment at home and abroad.it is so obviously any holder of payment card if he travelled to abroad countries for business or holiday, at the moment he favored Visa, Master, Amex or Diner card at abroad payment center. They so accepted widely and globally. This means in other words, if somebody interested to travel abroad countries no need to carry large amount of money with you or even no need to carry plenty cheques. It is sufficient to just hold your payment card.

Thirdly:-

Credit or payment card would arrange the obligations between three parties ; the bank will obligate to clear the cost of prices on behalf of holder of the card, the business center is obligated to accept the card for the clearance of goods and finally holders obligated before the bank to clear the balance.

\section{Fourth:-}

Payment cards having more advantages over travelling cheques or even currency because both of them they need more time to be spent than payment cards.

Fifth:-

customers protection; because in the Law of business the purchased goods should delivered successfully to the customers in case there is failure for deliverance to the purchased goods the customer with the usage of payment card could be able to refund his money or compensated.

\section{Sixth:-}

Customers who are card holders are eligible to meet discount or get bonuses when they will go to private health or medical center or when their cars need repairing or if they want to spent their holidays at club.

\section{Seventh:-}

Issuance payment cards determine the holder of the card had already opened an account with bank because when the bank paid the purchased goods on behalf of the card holder it means customer already deposit amount of money with him.

\section{Eighth: -}

Free insurance cover; some card holders may not be aware that some credit payment card may occasionally come with their free insurance which covering the goods or services. These might come in to three categories such as:-

1. Replacement of goods ;if for example the goods that you have purchased with the card has been damaged, lost or stolen within three month some card issuers will guarantee for you the replacement.

2. Travelling accident insurance: some card issuers include in to their card holders to insured for the risk of travelling or risk of life then if the holder of the card on the land affected with serious injuries within the travelling they will be insured

3. 3) Insurance for the delay of travelling: if the preparations for travelling had been delayed for any reason some card issuers include payment of a compensation for the travellers.

Ninth:-issuance of Bank payment card through the electronic system involve availability of international organization that issues these cards such as visa and master card to include very sophisticated banking operational system to settle the payment between the banks. 


\section{TYPES OF THE CREDIT CARDS:}

There are various types of the credit cards herein are some patterns: ${ }^{(5)}$

1) Standard Credit cards: They are two types:
a) Balance transfer Credit Cards
b) Low Interest Credit Cards

2) Credit Card with Rewards Programs : They are three Types
a) Airlines Credit Cards
b) Cash Back Credit Cards
c) Reward Credit Cards

3) Credit Cards for Bad Credit: They are two types:
a) Secured Credit Cards,
b) Prepaid Debit Cards,

4) Speciality Credit Cards: They are two types
a) Business Credit Cards,
b) Student Credit Cards,

\section{Brief Explanation about every type (6):}

1) Standard Credit cards: which are two types of Credit Cards;

Balance transfer Credit cards / Lower Transfer Credit Cards. The balance transfer credits Cards are designed to permit customer to transfer higher interest credit cards into a credit card with Lower interest rate which will save the money as interest between the values of the transfered credit cards.

2) Credit Cards with Reward Programs ; which are three:

a) Air lines Credit Cards: This type of credit card whenever you use if Air Lines miles we credit to you it used to be called: frequent flyer miles. These types of cards are greater for customers or holder who always or frequently travels.

b) Cash Back Credit Cards: These types of cards will be customers reward based on what they purchased. The more holders used the card the more they will get reward.

c) Reward Credit Cards: The name of this card reflecting and bearing its meaning without more explanation.

3) Credit Cards for Bad Credit : They are two categories:

a) Secured Credit Cards: To obtain this credit card a security deposit of a predetermined is needed in order to secure your credit card. Then a reward may come in a form of a car, boat, jewellery or else.

b) Prepaid Credit card: Prepaid credit card indeed they are not credit card but they are rather used as credit cards. The only advantage of this credit card there will be no financial charges and it will avoid the holder of the cards debts.

4) Speciality Credit Cards: They are two types as we mentioned earlier:

a) Business Credit Cards: this type of card for business man, executive and others the benefit is to get low introductory rate, cash back rewards, airlines rewards etc....

b) Student Credit Cards: Student generally find difficulty to get credit cards, therefore banks designed for them this type of the cards. The student's credit cards at time scaled back in terms of rewards feature and other type of benefits. 


\section{ISLAMIC JURISPRUDENTIAL PROVISIONS ON USAGE OF BANK CREDIT CARDS:-}

To provide the legality to use plastic credit card according to provision of Islamic jurisprudence's .Three views on legality should be implemented:-

Firstly:

Resolution of International Islamic of Jurists Assemblies at Arabia (12/02/108 الدولي) قرار مجمع الفقه الاسلامي Within its second summit held at Riyadh Saudi Arabia regarding validity of using bank credit cards , the summary of juristic resolution was as follows $(7)$ :-

1. It is totally prohibited to use bank credit card when the holder doesn't deposit sum of money in his account at the bank, like wise it is prohibited to use it. If the bank constitutes usurious increment of interest.

2. It is allowed to possess the bank credit card in case the holder doesn't have deposit on two cases :-

a) As cost for services rendered to the card holder by the bank or as a cost for renewal, or for clearance to the cost of the purchased commodities or service on behalf of the card holders.

b) The bank authorizes amount from the account of the card holder as commission for clearance the cost of purchased goods at business centers on behalf of the traders, customers since they are card holders

3. It is allowed for the card holders to withdraw from their deposited account if there is no usurious estipulate increment by the bank management.

4. It is totally ban or prohibited to sell and purchase gold, silver or foreign exchange currency with the usage of bank credit card when the holder doesn't own a sum of money equivalent to such transaction in his account at the moment that selling or purchasing is done .

\section{Secondly:-}

Juristic measures on the validity to the usage bank credit card with reference to document no (61) issued by Accounting and Auditing Organization for Islamic Financial Institutions : ${ }^{(8)}$ which bearing the title : Miyar Shariy no (61) item no (3-5) PP:6-10

1. The non renewable bank credit cards :-

a) Is instrument issued to enable holder to withdraw money within limited ceiling and on specific period of time.

b) Bank credit card can be used to pay the cost of purchased goods and services within specific agreed amount of money.

c) The bank that issued the credit card should never receive any amount or commission from the holder rather from the bank of the business center where the holder purchased goods or received services.

d) Bank normally received some commission deducted from the account of customers of other banks when they used their payment machines.

e) Banks the issuers of the credit card obligated to pay the cost of goods and services within specific agreed ceiling to the business centers through the international companies that introduced the credit cards.

f) The card holder obligated before the bank that issued the credit card to refund the costs of the purchased goods or services.

\section{The renewable bank credit cards :-}

a) This type of credit card is an instrument for withdrawal and payment for goods and services

b) In case of selling and purchasing or withdrawal, the holder of the card is not entitled to pay any usurious interest to the bank 


\section{The prescribed fees for bank credit cards :-}

a) The fees that enforced on card holder by the bank management should not be increased more than the normal fees that valid to all holders.

b) Incase if there is need to increase the fees of the credit card then the management of the bank should consider issuance fees, renewal fees, exchange card fees, exchanging currency fees etc..

c) Fees enforced on card holder based on negotiation between bank management and credit card holders:-

d) Fees that deducted by the bank of business centers where by percentage of these fees will refunded to the issuer of the card. While other specific percentage will be refunded to international company that organizing usage of credit card such as : VISA, MASTER CARD, AMEX,AMERICAN EXPRESS

e) Fees for participation and commission due to service rendered to international companies those organizing issuing bank credit cards.

f) Fees that prescribed by management of issuers bank for rendering services to card holders such as: cash withdrawal ,renewal, exchange of card and exchanging money with foreign currency.

g) Fees that prescribed and enforced by the management of the bank which owned ATM machine that dispersing cash payment to credit card holders.

\section{Bank Participation in Association of the International Organization for Issuance Credit Cards:}

a) Banks are Islamically authorized to participate in association of international companies such as visa, master card, Amax and others on condition that they should avoid establishment to all transaction that violate Shariah law eg: usury, selling galchoholic etc..

1. Banks are Islamically authorized to pay any prescribed fees due to their membership with international organization that used their regional companies to issue credit cards.

2. Banks are Islamically allowed to receive any encouragement donation offered by international organization that associated with to introduce banking credit cards.

Payment the prices of gold and silver with the usage of credit card:

Holders of bank credit cards are allowed to pay the prices of purchased silver and gold with observation and compliance to shariah laws that provided in the contract of exchanging currencies or in Arabic "Agdu Alsarf"

\section{Thirdly:}

Juristic "fatwas" Declared on Permissibility on the Usage of Bank Credit Cards: There were various fatwa or juristic declaration on permissibility of the usage of credit cards some of these specialized institutions:(9)

1. Qararat At haayat and shariah: masrif el rajhi Riyad, Arabia Saudia- which means "juristic resolution of monitoring panel at el-rajhi bank Saudi Arabia" No(869-2/1302H)

2. Qarart wa tawsyat nadwat el-baraka , legislated el islami which means " juristic resolution and recommendation for specialized committees at Islamic bank of Baraka at, Arabia witin the second summit pp:201-202

3. Al dawabid almustakhalsa min qararat al haiat el sharyayh li bank al bilad, which means "Juristric restrictions summery of resolutions for jurists panel at bank el bilad Arabia Saudia restriction no : $346 p$ : 101 
The above mentioned Islamic institutions constituted their ( fatwas): or jurist declarations on the following principles:

a) The basic rules that governs establishment of contract and supportive conditions is the permissibility. (10)

b) The usage of credit card should never involved any usurious practices or other prohibited contract, because the withdrawal would be done directly on the credit card of the holder.

c) The credit card is similar to other payment card which classified as lawful banks credit cards according to the fatwas or declared resolutions of international Juristics assemblies in the world as we mentioned in this context.

\section{CONCLUSION}

Findings: -

At the ending of this paper the researcher means to state the following findings:-

1. Financial credit cards such American Express, Visa, Amex and others offered by International Organizations.

2. Every credit card has three inter relations :

The producer of the card which is a bank; organization or business center.

$>$ The holder of the card who is a customer

$>$ The party who is offering services to the customers and received payment through financial cards.

3. The introductory organization to financial cards used to adopt very sophisticated financial techniques to settle payment of their holder of the cards and the cost of services and banks that offered the cards.

4. Banks presently used to issue different types of payment card therefore customer should determine at instance stage which card suitable for them.

5. There are different types of credit cards such as: reward credit card, balance transfer card, airlines credit cards, business credit card and others.

6. It is a prerequisite for a Credit holder to open account with bank that introduced the credit card.

7. The credit card might include life insurance or insurance against thief or armed robbery.

8. The credit card might be used for purchasing gold and silver.

9. Bank are authorized to collect some fees for rendering services to card holders such as : issuance of credit card, exchange domestic money to international money and other services

10. The national bank are allowed islamically to associate with international organizations that issued bank credit card such as visa master card, amex and others

\section{Recommendations:}

What follows are recommendations based on the research findings:

1. The provisions of Shariah law never prevent any new discovery, technology advancement since it is not contradict with the principles of Islam.

2. The international Islamic Juristrict assemblies as mentioned in this conference paper issued various fatwas to legality practice of plastic cards.

3. I advice the entire western European and American Universities to adopt learning and implement the Islamic banking and economic systems for their simplicity felexibility and justice. 


\section{NOTES AND REFERENCES}

1. Mustafa Syid Faird: Mutarjam bitagat Eliatiman, Dar al kutub Al ganooniyath , Egypt, Cairo ,p;6

2. Sayid Mustafa Ibid, p:6Bayer Amil Tabia: Bitagat Al iatimad wa alalgat al tagud yah, Dirasat Tahlyyah, Manshurat Al halabi Al huquqyyyah, Bairut(2000)pp:16-17

3. Faiz Naim Ridwan: Bitagat Al-daf alilactroni, Matbat Al fujrah, pp:18-19(the author is a professor in commercial law and dean faculty of law , police academy Dubai, UAE)

4. Faiz Naim Ridwan ibid, pp:20-22

5. Abdul wahab Abu sulaiman : Al bitagat Al bankiyyah ; Dirasat Fiqhyyat Qanoonyyat Tahlyyat, Dar algam Dimashq, second edition (1424 H-2003), PP;33-35- Mustafa sayidabdulwahid ,ibid,pp18-22

6. Saiyd Mustapha Abdul wahid : ibid :pp19-21

7. Faiz Naiem Ridwan, ibid ;pp;44-55: Resolution of international Islamic of Jurists of Riyadh, Arabia (No;108/2/12)

8. Document No (61) issued by accounting and auditing organization for Islamic financial institutions.

9. Yasir bin Ibrahim bin Mohammed El khuda: Al bitagat Al raqamyyat, Dirasat fiqahyyat tatal byqyyat (the author is a Lecturer (Ph.D) faculty of shariah ,Imam Mohammed Bin Saud University, Saudi Arabia, is a paper published on majalat el ulum al shariah, vol (50),(440H): PP 317-388

10. Shaikh Ahmed bin Tayymiyat; Majmooa Al Fatawa, jam wa tarteeb shaik abdul rahman bin Qasim, distribution of ministry of religious affairs, Saudi Arabia (1426H). 